\title{
Biochemical Methane Potential of Swine Slaughter Waste, Swine Slurry, and Its Codigestion Effect
}

\author{
Anriansyah Renggaman ${ }^{1,2} \mathbb{D}$, Hong Lim Choi ${ }^{1,3, *}$, Sartika Indah Amalia Sudiarto ${ }^{1,4}$, Andi Febrisiantosa 1,5 $\mathbb{D}$, \\ Dong Hyoen Ahn ${ }^{6}$, Yong Wook Choung ${ }^{6}$ and Arumuganainar Suresh ${ }^{7}$ (D)
}

1 Department of Agricultural Biotechnology, Research Institute for Agriculture and Life Sciences, Seoul National University, Seoul 151-742, Korea; anriansyah88@gmail.com (A.R.); sartikasudiarto_r@yahoo.com (S.I.A.S.); andi.febrisiantosa@gmail.com (A.F.)

2 Microbial Biotechnology Research Group, Institut Teknologi Bandung, School of Life Science and Technology, Bandung 40132, Indonesia

3 Resourcification Research Center for Crop-Animal Farming, Seoul 08800, Korea

4 Ecology Research Group, Institut Teknologi Bandung, School of Life Science and Technology, Bandung 40132, Indonesia

5 Research Unit for Natural Product Technology, Indonesian Institute of Sciences, Yogyakarta 55861, Indonesia

6 GreenLabs, Seoul 05854, Korea; lukeahn@greenlabs.co.kr (D.H.A.); yw.jung@greenlabs.co.kr (Y.W.C.)

7 Waste Management Unit, Suguna Foods Private Limited, Udumalaipettai 642126, India; suresha@sugunafoods.com

* Correspondence: ulsoo8@snu.ac.kr; Tel.: +82-2-880-4808; Fax: +82-2-874-4808

Citation: Renggaman, A.; Choi, H.L.; Sudiarto, S.I.A.; Febrisiantosa, A.; Ahn, D.H.; Choung, Y.W.; Suresh, A. Biochemical Methane Potential of Swine Slaughter Waste, Swine Slurry, and Its Codigestion Effect. Energies 2021, 14, 7103. https://doi.org/ 10.3390/en14217103

Academic Editor: Attilio Converti

Received: 5 October 2021

Accepted: 27 October 2021

Published: 31 October 2021

Publisher's Note: MDPI stays neutral with regard to jurisdictional claims in published maps and institutional affiliations.

Copyright: (c) 2021 by the authors. Licensee MDPI, Basel, Switzerland. This article is an open access article distributed under the terms and conditions of the Creative Commons Attribution (CC BY) license (https:/ / creativecommons.org/licenses/by/ $4.0 /)$.

\begin{abstract}
The codigestion of slaughter waste with animal manure can improve its methane yield, and digestion parameters; however, limited studies are available for the effectiveness of anaerobic codigestion using swine slaughter waste (SSW) and swine slurry (SS). Hence, this study was conducted to determine the characteristics of SSW and the effect of anaerobic codigestion with (SS) and explored the potential of $\mathrm{CH}_{4}$ production $\left(M_{\max }\right)$, the lag phase period $(\lambda)$, and effective digestion time $\left(T_{\text {eff }}\right)$. SSW contains fat and protein contents of $54 \%$ and $30 \%$ dry weight within $18.2 \%$ of solid matters, whereas SS showed only $6 \%$ and $28 \%$ within $4.1 \%$ of solid matters, respectively. During sole anaerobic digestion, SSW produced a high $M_{\max }\left(711 \mathrm{Nml} \mathrm{CH}_{4} / \mathrm{g} \mathrm{VS}_{\text {added }}\right)$ but had a long duration $\lambda$ ( $~ 9$ days); whereas SS produced a low $M_{\max }\left(516 \mathrm{Nml} \mathrm{CH}_{4} / \mathrm{g} \mathrm{VS}_{\text {added }}\right)$ but had a shorter duration $\lambda$ ( 1 day). Codigestion increased the $M_{\text {max }}$ from $22-84 \%$ with no significant $T_{\text {eff }}$ compared to sole SS digestion. However, the low $M_{\max }$ of SS and high $\mathrm{M}_{\max }$ of SSW, resulted in a 7-32\% decrease in $M_{\max }$ at codigestion compared to SSW sole digestion. Codigestion improved the digestion efficiency as it reduced $\lambda$ (3.3-8.5 days shorter) and $T_{\text {eff }}$ (6.5-9.1 days faster) compared to SSW sole digestion. The substrate-to-inoculum ratio of 0.5 was better than 1 ; the volatile solid and micronutrient availability may be attributed to improved digestion. These results can be used for the better management of SSW and SS for bio-energy production on a large scale.
\end{abstract}

Keywords: anaerobic digestion; swine slaughter waste; swine slurry; codigestion; $\mathrm{CH}_{4}$ production; lag phase period

\section{Introduction}

A drastic increase in meat consumption per capita from $13.9 \mathrm{~kg}$ in 1980 to $53.9 \mathrm{~kg}$ in 2018 was observed in South Korea, and this resulted in an increased amount of slaughtered livestock [1]. This also increased the generation of by-products (slaughter waste) from the slaughtered livestock. It was reported that 16.7 million swine were slaughtered in 2017 and around 260,018 tons of swine slaughter waste (SSW) was generated in South Korea [2]. SSW mainly contains blood, viscera (digestive tract tissues), and offal (internal organs) not intended for human consumption [3,4]. It contains highly volatile solids (VSs) from fat and protein content, which indicated that SSW was an energy-rich waste. Previously, South Korea disposed of SSW through ocean dumping, composting, recycling as animal feed, 
and land fill. However, in 2012, ocean dumping was prohibited in South Korea. Moreover, there has recently been an interest in utilizing slaughter waste as a substrate for anaerobic digestion $[1,5,6]$.

Around 13 million tons of swine slurry (SS) is produced in South Korea every year [7]. SS contains a large amount of organic matter (found in around $0.6-12.6 \%$ of its total solids (TS)) and exists mainly in the liquid form [8,9]. Its accumulation leads to greenhouse gas and odor emission during storage and soil and water pollution through runoff and leachate. In addition, slurry transportation is uneconomical; therefore, on-site treatment is preferable [8].

Kim et al. [10] reported that 49 biogas plants were available in South Korea, 9 of which treated livestock manure and 13 which used a mixture of swine manure and food waste or any other organic mixtures. These biogas plants were characterized as uneconomical due to their high operational cost and low amount of methane production. It was also reported that biogas production using a sole substrate, such as livestock manure alone, was not economically sustainable [11], whereas codigestion might be profitable. The codigestion of two or more organic wastes was preferred to improve digestion stability and $\mathrm{CH}_{4}$ production [12-16]. The positive effects of codigestion are the dilution of inhibitory compounds, a better macro- and micronutrient balance, the improvement of buffering capacity, and balance of the VSs content of the mixture [17]. The substrates utilized for codigestion were selected based on several factors such as compatibility and geographical availability [17].

SS consists of high macro- and micronutrients and a high buffering capacity but low VSs, which result in a low $\mathrm{CH}_{4}$ yield during the anaerobic digestion process [18], whereas SSW contains low macro- and micronutrients and a low buffering capacity but a high content of VSs. In terms of geographical availability, a slaughterhouse is usually located near a livestock farming facility to reduce transportation costs. Hence, the codigestion of livestock waste and slaughter waste is a feasible option to improve the anaerobic digestion parameters such as the maximum $\mathrm{CH}_{4}$ potential production $\left(M_{\max }\right)$, lag phase period $(\lambda)$, ionand effective digest time $\left(T_{\text {eff }}\right)$. However, very limited studies are available for the codigestion effect of SSW and SS on methane yield and digestion parameters. Therefore, the objectives of this study were to determine the characteristics (the chemical, proximate, ultimate, energy content, and biomethane potential (BMP) characteristics) of SSW and SS and improve anaerobic digestion through codigestion. These results can be referred to in order to improve the bio-energy production of SSW and SS on a large scale.

\section{Materials and Methods}

\subsection{Experimental Design (Substrates and Inocula)}

The SSW samples were collected from a slaughterhouse in Yeongcheon City, Gyeongsang Province, South Korea, which slaughtered around 189,466 swine in 2017 [2]. The samples collected consisted of livestock remains except for blood, brain, bones, and spinal cord. Blood was omitted since it was processed separately by the slaughterhouse. Brain, spinal cord, and skin hairs were also omitted due to safety reasons. The sample mostly contains intestines, feeds left-over in the stomach, and flushing contents. SS was collected from the swine farm in Hoengseong County, Gangwon Province, South Korea. The samples were mixed separately (ground into SSW using a fruit mixer), sieved $(<5 \mathrm{~mm})$ and dried at $105{ }^{\circ} \mathrm{C}$ for $12 \mathrm{~h}$, and used for chemical, ultimate, and higher heating value (HHV) analysis. The wet sample was utilized for the proximate and BMP analyses. The inoculum was collected from a mesophilic anaerobic digester treating SS (active anaerobic digester in Suwon campus) and used for the BMP experiment. The inoculum was maintained in a serum bottle $(250 \mathrm{~mL})$ with the addition of SS and SSW once a month. Before the experiment, the inoculum was degassed for two weeks to deplete any remaining organic materials and gas production. Table 1 shows the characteristics of the inoculum utilized in both BMP and codigestion experiments. 
Table 1. Anaerobic inoculum characteristics.

\begin{tabular}{ccc}
\hline Parameter $^{\mathbf{1}}$ & BMP Experiment $^{\mathbf{2}}$ & Codigestion Experiment $^{\mathbf{2}}$ \\
\hline TS (mg/L) & $39,111 \pm 798$ & $39,786 \pm 1515$ \\
VS (mg/L) & $21,515 \pm 602$ & $25,354 \pm 5035$ \\
VS/TS & 0.55 & 0.64 \\
pH & $7.73 \pm 0.0$ & $7.69 \pm 0.0$ \\
\hline
\end{tabular}

${ }^{1}$ TS: total solid; VS: volatile solid (organic matter). ${ }^{2}$ Values expressed as mean \pm standard deviation.

\subsection{BMP Analysis and Codigestion Experiment}

The BMP of SSW and SS was measured using 250-mL serum bottles. The substrate-toinoculum ratio (S/I ratio, 1 and 0.5 ) was selected based on the vs. content of the substrate and inocula [5]. The total volume of the digestion was set at $200 \mathrm{~mL}$. The head space was filled with $\mathrm{CO}_{2}$ and $\mathrm{N}_{2}$ gas (20:80\% volume per volume), and the bottle was sealed with a butyl rubber cap and aluminum crimps and incubated at $35^{\circ} \mathrm{C}$ for 50 days. The control experiment was conducted by adding inocula and distilled water only. The codigestion experiment of SSW and SS was performed in five different SSW samples per SS (SSW /SS) ratio of 1:0, 0:1, 2:1, 1:1, and 1:2, on a $w / w$ vs. basis. This was equal to a $100 \%(946 \mathrm{~g} \mathrm{VS} / \mathrm{L})$, $0 \%$ (676 g VS/L), 67\% (875 g VS/L), 50\% (811 g VS/L), and 33\% (765 g VS/L) vs. basis of SSW content in the codigested mixture (Table 2). The experiments were also performed at an S/I ratio of 1 and $0.5 w / w$ vs. basis, and the procedure followed was the same as that for the BMP test. Then, $50 \mathrm{~mL}$ of the mixture was sampled for further analysis.

Table 2. Experimental design of anaerobic codigestion experiment of SSW with SS and its mixtures.

\begin{tabular}{cccc}
\hline \multirow{2}{*}{ Code } & \multicolumn{3}{c}{ Substrate $\left(\%\right.$ vs. Basis) $^{\mathbf{1}}$} \\
\cline { 2 - 4 } & SSW & SS & OLR g VS/L $^{\text {P1 }}$ \\
P2 & 100 & 0 & 946 \\
P3 & 0 & 100 & 676 \\
P4 & 67 & 33 & 857 \\
P5 & 50 & 50 & 811 \\
\hline
\end{tabular}

${ }^{1}$ The S/I ratio of 1 (A) and 0.5 (B) was used for all the mixtures, and experiments were performed in triplicate.

\subsection{Analytical Methods}

\subsubsection{Chemical, Proximate, Ultimate Analysis, and Mineral Content}

Chemical analysis of fat, protein, neutral detergent fiber (NDF), and acid detergent fiber (ADF) was performed in SSW and SS. Fat content was determined by Soxhlet extraction with ether as solvent. Protein content was determined with total Kjeldahl nitrogen (TKN). NDF and ADF contents were determined according to the study by Fernández-Cegrí et al. [19]. Proximate analyses of moisture, TS, VS, and fixed solids (FS) were performed by standard methods [20]. Before ultimate (elemental) analysis, samples were pretreated following the procedure described in the study by Choi et al. [21]. Carbon $(\mathrm{C})$, hydrogen $(\mathrm{H})$, nitrogen $(\mathrm{N})$, and sulfur $(\mathrm{S})$ contents of pretreated samples were analyzed with an elemental analyzer (Flash EA 1112, Thermo Fisher Scientific, Dreieich, Germany). The oxygen (O) content of the samples was analyzed using a Flash 2000 elemental analyzer (Thermo Fisher Scientific, Germany). The mineral contents such as cobalt $(\mathrm{Co})$, iron $(\mathrm{Fe})$, molybdenum (Mo), nickel (Ni), tungsten (W), and zinc ( $\mathrm{Zn})$ of SSW and SS were analyzed by inductively coupled plasma atomic emission spectroscopy (ICP-7510, Shimadzu Corp., Kyoto, Japan). Before the analysis, the samples were digested with nitric acid-hydrochloric acid (method number 3030F) [20].

\subsubsection{HHV Analysis}

Dried samples were ground using a mortar and pestle and sieved (5 mm) (DH.Si8021, DAIHAN Scientific, Gangwon-do, Korea), then pelletized using a pellet press (2811, Parr Instrument), and analyzed using an oxygen bomb calorimeter (Model 1341 plain jacket 
calorimeter, Parr Instrument). Benzoic acid pellets (3415, Parr Instrument) were used to standardize the oxygen bomb calorimeter prior to the analysis.

\subsubsection{Biogas Production, Composition, and Specific $\mathrm{CH}_{4}$ Yield}

The biogas production was analyzed using the manometric method, in which constant volume was maintained and headspace pressure increase was measured using a pressure transducer [22]. The excess gas was released regularly and quantified using a glass syringe until the pressure was similar to that at the start of the incubation [23]. The gas composition was analyzed using a gas chromatograph HP 6890N (Agilent Technologies) equipped with an HP-PLOT Q column (Agilent Technologies) and a thermal conductivity detector. The inlet, oven, and detector temperatures were $40^{\circ} \mathrm{C}, 35^{\circ} \mathrm{C}$, and $200^{\circ} \mathrm{C}$, respectively. The $\mathrm{CH}_{4}$ content was then utilized to determine $\mathrm{CH}_{4}$ production and, subsequently, the specific methane yield (SMY) using Equation (1):

$$
\mathrm{SMY}=(\mathrm{MP} / \mathrm{VS})\left(t_{0} / t_{\mathrm{i}}\right)
$$

where SMY is the specific $\mathrm{CH}_{4}$ yield, in $\mathrm{Nml} \mathrm{CH}_{4} / \mathrm{g} \mathrm{VS}_{\text {added }}$ or $\mathrm{NL} \mathrm{CH}_{4} / \mathrm{kg} \mathrm{VS}_{\text {added }}$; MP is the $\mathrm{CH}_{4}$ production, in $\mathrm{mL}$; vs. is the volatile solid content of initial samples, in $\mathrm{g}$; $t_{0}$ is the temperature under a standard condition, $273 \mathrm{~K}$; and $t_{\mathrm{i}}$ is the temperature where the experiment was conducted, $308 \mathrm{~K}$.

\subsubsection{Theoretical $\mathrm{CH}_{4}$ Yield (TMY)}

Elemental analysis was used to determine the chemical formula of organic waste [5]. TMY can be determined empirically from the chemical formula of organic waste suggested by Symons and Buswell [24], and Boyle [25]. Equation (2) was used to determine theoretical $\mathrm{CH}_{4}$ from the chemical formula of organic waste [5,26]. This equation considered the production of carbon dioxide $\left(\mathrm{CO}_{2}\right)$, ammonia $\left(\mathrm{NH}_{3}\right)$, and hydrogen sulfide $\left(\mathrm{H}_{2} \mathrm{~S}\right)$ gas, which were the by-products of anaerobic digestion complex substrates:

$$
\mathrm{C}_{\mathrm{a}} \mathrm{H}_{\mathrm{b}} \mathrm{O}_{\mathrm{c}} \mathrm{N}_{\mathrm{d}} \mathrm{S}_{\mathrm{e}}+\mathrm{xH}_{2} \mathrm{O} \rightarrow \mathrm{yCH}+\mathrm{zCO}_{2}+\mathrm{dNH}_{3}+\mathrm{eH}_{2} \mathrm{~S}
$$

The reaction coefficient for $\mathrm{H}_{2} \mathrm{O}(\mathrm{x}), \mathrm{CH}_{4}(\mathrm{y})$, and $\mathrm{CO}_{2}(\mathrm{z})$ can be determined using Equation (3):

$$
\begin{aligned}
& x=\left(a-\frac{b}{4}-\frac{c}{2}+\frac{3 d}{4}+\frac{e}{2}\right) \\
& y=\left(\frac{a}{2}+\frac{b}{8}-\frac{c}{4}-\frac{3 d}{8}-\frac{e}{4}\right) \\
& z=\left(\frac{a}{2}-\frac{b}{8}+\frac{c}{4}+\frac{3 d}{8}+\frac{e}{4}\right)
\end{aligned}
$$

The TMY of organic waste at a standard temperature and pressure of $1 \mathrm{~atm}$ and $273 \mathrm{~K}$ can be determined using Equation (4) as suggested by Pellera and Gidarakos [27]:

$$
\mathrm{TMY}=1000 \mathrm{y} /(12 \mathrm{a}+\mathrm{b}+16 \mathrm{c}+14 \mathrm{~d}+32 \mathrm{e})
$$

where TMY is the theoretical $\mathrm{CH}_{4}$ yield, in $\mathrm{Nml} \mathrm{CH}_{4} / \mathrm{g}$ VS.

The degree of anaerobic degradation $\left(D_{\mathrm{deg}}\right)$ was determined using Equation (5):

$$
D_{\text {deg }}=\mathrm{TMY} / \mathrm{SMY} \times 100
$$

where $D_{\text {deg }}$ is the degree of anaerobic degradation, in \%.

\subsubsection{Kinetic Model}

The biogas production curve during anaerobic digestion of the complex organic material corresponds to a slower flat curve [28]. Thus, the lag phase $(\lambda)$ is also an important factor determining anaerobic digestion efficiency, as well as the cumulative $\mathrm{CH}_{4}$ yield 
(CMY) and $\mathrm{CH}_{4}$ production rate [29]. Using the modified Gompertz formula, $\lambda$ can be estimated as follows [30]:

$$
M(t)=M_{\max } \exp \left\{-\exp \left[\frac{R_{\max } \mathrm{e}}{M_{\max }}(\lambda-1)+1\right]\right\}
$$

where $M(t)$ is the $\mathrm{CMY}$ at digestion time $t$, in $\mathrm{NmL} \mathrm{CH}_{4} / \mathrm{g} \mathrm{VS}_{\text {added }} ; M_{\max }$ is the maximum $\mathrm{CH}_{4}$ production potential, in $\mathrm{NmL} \mathrm{CH} \mathrm{CH}_{4} / \mathrm{g} \mathrm{VS}_{\text {added }} ; R_{\max }$ is the maximum $\mathrm{CH}_{4}$ production rate, in $\mathrm{NmL} \mathrm{CH}_{4} / \mathrm{g} \mathrm{VS}_{\text {added }}$ /day; $\lambda$ is the lag phase period, in days; $t$ is the observation time, in days; and $e$ is the $\exp (1)=2.7183$.

A nonlinear least-squares regression analysis was performed using Excel solver add-in to determine $M_{\max }, R_{\max }, \lambda$, and correlation coefficient $\left(R^{2}\right)$ of the produced model. In addition, the Excel solver was also used to estimate $T_{90}$ that is the time required to obtain $90 \% M_{\max }$. Using $T_{90}$ and $\lambda$, the effective digestion time $\left(T_{\text {eff }}\right)$ can be calculated by using Equation (7):

$$
T_{\text {eff }}=\mathrm{T}_{90}-\lambda
$$

where $T_{\text {eff }}$ is the effective digestion time, in days; and $T_{90}$ is the time required to obtain $90 \%$ $M_{\text {max }}$, in days.

The simulated maximum $\mathrm{CH}_{4}$ production potential of the codigested mixture $\left(M_{\text {sim }}\right)$ was calculated by the proportion of SSW and SS in the mixture and the $M_{\max }$ was estimated using the modified Gompertz formula for the sole SSW or SS anaerobic digestion, as shown in Equation (8) [29]:

$$
M_{\text {sim }}=M_{\text {SSW }} \times \% \mathrm{Y}_{\mathrm{SSW}}+M_{\mathrm{SS}} \times \% \mathrm{Y}_{\mathrm{SS}}
$$

where $M_{\text {sim }}$ is the simulated maximum $\mathrm{CH}_{4}$ production potential of the codigested mixture obtained from the modified Gompertz formula, in $\mathrm{NmL} \mathrm{CH}_{4} / \mathrm{g} \mathrm{VS}_{\text {added }} ; M_{\mathrm{SSW}}$ is the $M_{\max }$ of SSW obtained from the modified Gompertz formula, in $\mathrm{NmL} \mathrm{CH}_{4} / \mathrm{g} \mathrm{VS}_{\text {added }} \% \mathrm{Y}_{\mathrm{SSW}}$ is the percentage of SSW in the mixture, in \%; $M_{S S}$ is the $M_{\max }$ value of SS obtained from the modified Gompertz formula, in $\mathrm{NmL} \mathrm{CH}_{4} / \mathrm{g} \mathrm{VS}_{\text {added }}$; and \% $\mathrm{Y}_{\mathrm{SS}}$ is the percentage of $\mathrm{SS}$ in the mixture, in \%.

\subsubsection{Synergistic Effect}

The synergistic effect is inner reactions produced by the codigestion of different components. Each codigested substrate can influence the $\mathrm{CH}_{4}$ production rate [31]. The synergistic effect was calculated using Equation (9):

$$
\alpha=M_{\text {codigestion }} / M_{\text {sim }}
$$

where $M_{\text {codigestion }}$ is the experimental $M_{\max }$ obtained from the modified Gompertz formula (Equation (8)) of the codigested substrate, in $\mathrm{NmL} \mathrm{CH}_{4} / \mathrm{g} \mathrm{VS}$ added.

The $\alpha$ value determines the type of synergistic relation among codigested substrates. Specifically, $\alpha>1$ indicated that codigested substrates have a synergistic effect, $\alpha=1$ indicated that codigested substrates work independently during the digestion process, and $\alpha<1$ indicated that codigested substrates have an antagonistic effect [31].

\subsubsection{Statistical Analysis}

The one-tail t-test was performed to compare the anaerobic digestion parameters (SMY, $M_{\max }, R_{\max }, \lambda, \mathrm{T}_{90}$, and $T_{\text {eff }}$ ) of SSW and SS at different S/I ratios. One-way analysis of variance followed by Tukey's honest significant difference test was performed to determine the effect of SSW codigestion with SS on the anaerobic digestion parameters at the same $\mathrm{S} / \mathrm{I}$ ratio (1 or 0.5$)$. The statistical significance level was set at $p<0.05$ for all the analyses. 


\section{Results and Discussion}

\subsection{Characteristics of SSW and SS}

The characteristics of SSW and SS are shown in Table 3. SSW showed less TS (18.2\%) than previous studies, which reported $27.9 \%$ and $55 \%$ TS $[18,32,33]$. This might be attributed to the amount of water used for flushing and cleaning in the slaughterhouse before sample collection. However, the vs. content was noted as $94.57 \%$ of TS (\% DW) and mainly consisted of protein $(30.44 \% \mathrm{DW})$ and fat $(53.64 \% \mathrm{DW})$, indicating an energy-rich substrate. Interestingly, the fat and protein contents were higher than those previously reported in South Korea by Yoon et al. [5] who found $15.1 \%$ fat and $40.1 \%$ protein DW in SSW. The difference might be due to the offal that increased the fat content. Some studies found that swine offal had fat and protein contents between 41.8 and $65.76 \%$, and 20.1 and $31.6 \%$ DW, respectively $[18,33]$.

Table 3. Characteristics of SSW and SS.

\begin{tabular}{cccc}
\hline Parameters (\% Dry Weight) & SSW $^{\mathbf{1}}$ & SS $^{\mathbf{1}}$ & SSW/SS \\
\hline TS & $18.20 \pm 0.7^{\mathrm{B}}$ & $4.1 \pm 0.2^{\mathrm{A}}$ & 4.4 \\
VS in TS & $94.57 \pm 0.2^{\mathrm{B}}$ & $67.6 \pm 0.8^{\mathrm{A}}$ & 1.4 \\
FS in TS & $6.82 \pm 0.6^{\mathrm{A}}$ & $32.4^{\mathrm{A}} \pm 0.8^{\mathrm{B}}$ & 0.21 \\
TKN & $4.87 \pm 1.0^{\mathrm{A}}$ & $4.5 \pm 0.1^{\mathrm{A}}$ & 1.08 \\
Protein & $30.44 \pm 6.1^{\mathrm{A}}$ & $28.1 \pm 0.9^{\mathrm{A}}$ & 1.08 \\
Fat & $53.64 \pm 1.9^{\mathrm{B}}$ & $5.6 \pm 0.2^{\mathrm{A}}$ & 9.6 \\
NDF & $7.26 \pm 1.8^{\mathrm{A}}$ & $27.4 \pm 0.8^{\mathrm{B}}$ & 0.26 \\
ADF & $3.45 \pm 1.0^{\mathrm{A}}$ & $10.7 \pm 0.0^{\mathrm{B}}$ & 0.32 \\
Hemicellulose & $3.81 \pm 0.9^{\mathrm{A}}$ & $16.7 \pm 0.8^{\mathrm{B}}$ & 0.23 \\
C/N & $16^{\mathrm{N}}$ & $7.8^{-1}$ & 2.1 \\
\hline
\end{tabular}

${ }^{1}$ Values expressed as mean \pm standard deviation. ${ }^{\mathrm{A}, \mathrm{B}}$ Means in the same row with different uppercase letters differ significantly $(p<0.05)$. SSW, swine slaughter waste; SS, swine slurry; TS, total solids; VS, volatile solids; FS, fixed solids; TKN, total Kjeldahl nitrogen; NDF, neutral detergent fiber; ADF, acid detergent fiber; $\mathrm{C} / \mathrm{N}$, carbon to nitrogen ratio.

The TS content of SS was observed to be $4.1 \%$ with $67.6 \%$ vs. of DW, indicating a high mineral (FS) content. The protein $(28.1 \% \mathrm{DW})$ and NDF $(27.4 \% \mathrm{DW})$ contributed to the vs. content, which originated from the swine manure and wasted feed $[7,8]$. Moreover, the manure itself contained undigested feed material from the digestive tract. The TS and vs. contents of SS were within the ranges between 0.6 and $12.6 \%$ DW and between 56 and $84 \%$ DW, as previously reported in South Korea, respectively [9]. SSW contains higher vs. and fat contents than SS, while SS showed higher FS, NDF, ADF, and hemicellulose contents than SSW. Fat is an energy-rich substance, indicating that SSW has a higher energy content than SS. Additionally, a high vs. content indicated that more organic matter was available in SSW to be converted into $\mathrm{CH}_{4}$ during anaerobic digestion. SSW showed lower mineral contents $\left(6.82 \%\right.$ as FS) than SS $(32.4 \%)$, which might inhibit the $\mathrm{CH}_{4}$ generation rate when used alone for the digestion. Therefore, the codigestion of SSW with SS might contribute enough minerals for the microbes in the digestion, resulting in an enhanced $\mathrm{CH}_{4}$ production.

\subsection{Energy Content of SSW and SS}

SSW showed a high energy content with an HHV of $28.43 \mathrm{MJ} / \mathrm{kg}$ DW, which was higher than that of any of the renewable resources. Figure 1 shows that energy crops had an HHV between 14.69 and 20.71 MJ/kg DW [34,35], whereas the livestock manure collected in South Korea had an HHV between 11.92 and 19.44 MJ/kg DW [21]. Palm kernels had the highest HHV (21 MJ/kg DW) among the energy crops, while SS had the highest HHV (17.6 MJ/kg DW) among the livestock waste. The high HHV of SSW indicated that it had the potential to be used as a substrate for bio-energy production. SS had an HHV of 17.6 MJ $/ \mathrm{kg}$ DW, and was within the range (11.9-19.44 MJ $/ \mathrm{kg}$ DW) of HHVs from livestock waste in South Korea [21]. Moreover, it was suggested that the HHV and vs. had a positive 
correlation $[21,34,35]$. In the case of fresh weight, the SSW and SS (Table 3) exhibited an $\mathrm{HHV}$ of 5.17 and $0.72 \mathrm{MJ} / \mathrm{kg}$ FW, respectively. This showed that the physical energy valorization from SSW and SS was not sustainable due to the small amount of energy that could be recovered from the thermal treatment of fresh SSW and SS [26]. Thus, alternative technology to recover energy from SSW and SS is necessary. Any VS-containing substrates can be used in anaerobic digestion process for making biogas (VS converted to biogas) and successfully applied in large-scale digester systems across Europe [36]. Thus, anaerobic digestion could be an alternative technology to recover energy from SSW and SS.

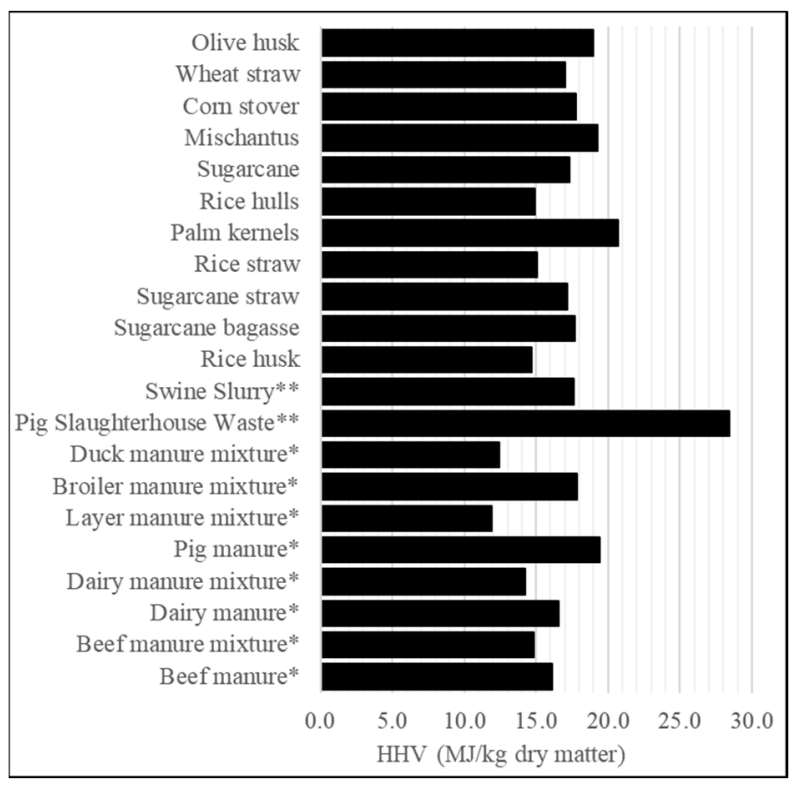

Figure 1. Comparison of the HHV of SSW, SS, and bio-wastes. ${ }^{* *}$ This study. ${ }^{*}$ Average value of 12 samples $[21,34,35]$.

\subsection{Anaerobic Digestion of SSW and SS}

Table 4 shows the ultimate analysis, empirical chemical formula, TMY, SMY, and $D_{\text {deg }}$ of SSW and SS. The S/I ratio had a significant effect on the SMY and $D_{\mathrm{deg}}$ of SSW and SS $(p<0.05)$. The SMY and $D_{\text {deg }}$ of SSW were 611.5 and $711.2 \mathrm{Nml} \mathrm{CH}_{4} / \mathrm{g} \mathrm{VS}$ added, and 84.3 and $98 \%$ at an S/I ratio of 1 , and 0.5 , respectively. TMY was observed at $725.5 \mathrm{Nml} \mathrm{CH}_{4} / \mathrm{g}$ vs. of SSW. Following this finding, Yoon et al. [5] reported that the anaerobic digestion of


offal showed a high SMY of $866 \mathrm{Nml} \mathrm{CH}_{4} / \mathrm{g} \mathrm{VS}$ added [18], mixed SSW (blood, meat, fat, and flour). A study in Denmark showed the highest SMY of $620 \mathrm{Nml} \mathrm{CH}_{4} / \mathrm{g} \mathrm{VS}$ added [32], and SSW (meat tissue, fat, bristles, and intestinal wastes) from Poland showed an SMY of $839.2 \mathrm{Nml} \mathrm{CH}_{4} / \mathrm{g} \mathrm{VS}_{\text {added }}$ [14]. A wide range of SMY from SSW occurred because of variations in the SSW and inoculum characteristics.

In the case of SS, the TMY was $529.5 \mathrm{Nml} \mathrm{CH}_{4} / \mathrm{g}$ VS, whereas the SMY and $D_{\text {deg }}$ were 310.1 and $516.3 \mathrm{Nml} \mathrm{CH}_{4} / \mathrm{g} \mathrm{VS}_{\text {added }}$ and 58.6 and $97.5 \%$ at an S/I ratio of 1 and 0.5 , respectively. The S/I ratio of 1 indicated a lower degradability in SS than in SSW (84\%). This might be due to the low vs. content observed in the SS. Previous studies demonstrated similar methane yields from SS. Zhang et al. [29], and Rodríguez-Abalde et al. [18] reported that the SMY from the anaerobic digestion of swine manure were $358.7 \mathrm{Nml} \mathrm{CH}_{4} / \mathrm{g} \mathrm{VS}_{\text {added }}$, and $204 \mathrm{Nml} \mathrm{CH}_{4} / \mathrm{g} \mathrm{VS}_{\text {added, }}$ respectively. Chae et al. [37] observed 228-437 $\mathrm{Nml} \mathrm{CH}_{4} / \mathrm{g}$ vs. at SS feed loads between $5 \%$ and $40 \%$ (v/v reactor). SSW was a better substrate than the SS in the anaerobic digester as, in this study, a higher degradability and SMY were found. 
Table 4. Ultimate analysis, empirical formula, TMY, SMY, and degree of anaerobic digestion $\left(D_{\mathrm{deg}}\right)$ from SSW and SS.

\begin{tabular}{|c|c|c|c|}
\hline Parameter $^{1}$ & SSW $^{2}$ & SS $^{2}$ & SSW/SS \\
\hline Carbon (\% DW) & $58.45 \pm 1.92$ & $37.3 \pm 0.3$ & 1.57 \\
\hline Hydrogen (\% DW) & $8.83 \pm 0.54$ & $5.2 \pm 0.0$ & 1.7 \\
\hline Oxygen (\% DW) & $22.14 \pm 3.48$ & $23.7 \pm 0.7$ & 0.93 \\
\hline Nitrogen (\% DW) & $3.66 \pm 0.00$ & $4.8 \pm 0.1$ & 0.76 \\
\hline Sulfur (\% DW) & $0.64 \pm 0.16$ & $1.0 \pm 0.1$ & 0.64 \\
\hline Empirical formula & $\mathrm{C}_{37.1} \mathrm{H}_{65} \mathrm{O}_{9.5} \mathrm{~N}_{3.2} \mathrm{~S}_{0.1}$ & $\mathrm{C}_{9.8} \mathrm{H}_{16.5} \mathrm{O}_{4.7} \mathrm{~N}_{1.1} \mathrm{~S}_{0.1}$ & \\
\hline TMY $\left(\mathrm{Nml} \mathrm{CH}_{4} / \mathrm{g} \mathrm{VS}_{\text {added }}\right)$ & $725.5 \pm 0.51^{\mathrm{B}}$ & $529.54 \pm 9.0^{\mathrm{A}}$ & 1.37 \\
\hline $\begin{array}{l}\text { SMY at an S/I ratio of } 1 \\
\left(\mathrm{Nml} \mathrm{CH}_{4} / \mathrm{g} \mathrm{VS} \text { added }\right)\end{array}$ & $611.5 \pm 13.2^{\mathrm{a}, \mathrm{B}}$ & $310.1 \pm 9.0^{\mathrm{a}, \mathrm{A}}$ & 1.97 \\
\hline $\begin{array}{l}\text { SMY at an } \mathrm{S} / \mathrm{I} \text { ratio of } 0.5 \\
\left(\mathrm{Nml} \mathrm{CH}_{4} / \mathrm{g} \mathrm{VS}_{\text {added }}\right)\end{array}$ & $711.2 \pm 9.9^{b, B}$ & $516.3 \pm 11.1^{\mathrm{b}, \mathrm{A}}$ & 1.38 \\
\hline$D_{\text {deg }}$ at an S/I ratio of $1(\%)$ & $84.3 \pm 1.8^{\mathrm{a}, \mathrm{B}}$ & $58.6 \pm 1.7^{\mathrm{a}, \mathrm{A}}$ & 1.44 \\
\hline$D_{\text {deg }}$ at an $\mathrm{S} / \mathrm{I}$ ratio of $0.5(\%)$ & $98.0 \pm 1.4^{\mathrm{b}, \mathrm{A}}$ & $97.5 \pm 2.1^{\mathrm{b}, \mathrm{A}}$ & 1 \\
\hline
\end{tabular}

$1 \%$ DW: $\%$ of dry weight. ${ }^{2}$ Values are expressed as mean \pm standard deviation. ${ }^{a, b}$ Means in the same column with different lowercase letters differ significantly $(p<0.05)$. ${ }^{\mathrm{A}, \mathrm{B}}$ Means in the same row with different uppercase letters differ significantly $(p<0.05)$.

The improvement of $D_{\mathrm{deg}}$ and SMY at a low S/I ratio was also observed in a previous study, where Yoon et al. [5] reported that the $D_{\operatorname{deg}}$ of the swine intestine residue and swine digestive tract content improved from 77.0 to $85.8 \%$ and from 69.9 to $86.3 \%$ when the S/I ratio reduced from 1 to 0.5 , respectively. The SMY was also improved from 361 to $446 \mathrm{~mL}$ $\mathrm{CH}_{4} / \mathrm{g} \mathrm{VS}_{\text {added }}$ of SSW at an S/I ratio of 1-0.5. The high inocula during batch anaerobic digestion could prevent VFA accumulation at the initial stage of anaerobic digestion and the rapid conversion of VFA into $\mathrm{CH}_{4}$ [38]; the same results were observed in this study. Moreover, high inoculums can dilute the toxic content in the substrate, which might explain the improvement of the SMY and $D_{\text {deg }}$ of SSW and SS at an S/I ratio of 0.5 than 1.

The modified Gompertz formula (Equation (6)) was used to estimate the maximum $M_{\max }, \mathrm{R}_{\max }, \lambda, M_{\max }, \mathrm{T}_{90}$, and $T_{\text {eff }}$, and the estimated parameters are shown in Table 5 . The estimated CMY from the modified Gompertz formula was plotted against the experimental CMY of SSW and SS to test the model accuracy (Figure 2). The correlation coefficient (R2) ranged from 0.989 to 0.999 (Table 5), indicating the best fit to the substrate used in the experiment. Previous studies also predicted the same accuracy, where the CMY curve from the anaerobic codigestion of SS, dewatered sewage sludge 2 and apple waste was best fitted with the modified Gompertz formula [29,30]. A low S/I ratio resulted in a higher $M_{\max }$ for SSW and SS $(p<0.05)$, whereas SSW had significantly higher $M_{\max }$ than SS at both S/I ratios $(p<0.05)$. The $M_{\max }$ was estimated for SSW at 598.7 and $723.7 \mathrm{Nml} \mathrm{CH}_{4} / \mathrm{kg} \mathrm{VS}$ added at an S/I ratio of 1 and 0.5 , whereas SS showed only 289.8 and $453.2 \mathrm{Nml} \mathrm{CH}_{4} / \mathrm{kg} \mathrm{VS}_{\text {added, }}$ respectively.

In addition to $M_{\max }, \lambda$ and digestion time ( $T_{90}$ and $T_{\text {eff }}$ ) were also important anaerobic digestion parameters. An indicator of methanogen adaptation to the environment, $\lambda$ also represented the substrate bio-availability $[33,39]$. The $\lambda$ was estimated at 9 and 9.7 days for SSW at an S/I ratio of 0.5 and 1, respectively (Table 5). Following this, Rodríguez-Abalde et al. [18] observed 7 days of $\lambda$ during the batch anaerobic digestion of SSW with a fat content of $65.7 \%$ DW. The long $\lambda$ indicated that the vs. in SSW was not readily available for the microbes and the microbial adaptation to a high fat content $[40,41]$. This could be related to a high fat content in the SSW $(53.6 \% \mathrm{DW})$, and fat requires more time for the anaerobic digestion [40]. 
Table 5. Anaerobic digestion parameters of SSW and SS estimated using the modified Gompertz formula (Equation (6)).

\begin{tabular}{|c|c|c|c|c|}
\hline \multirow{2}{*}{ Parameter * } & \multicolumn{2}{|c|}{$\mathrm{SSW}^{* *}$} & \multicolumn{2}{|c|}{ SS ** } \\
\hline & S/I Ratio of 1 & S/I Ratio of 0.5 & S/I Ratio of 1 & S/I Ratio of 0.5 \\
\hline$M_{\max }\left(\mathrm{Nml} \mathrm{CH}_{4} / \mathrm{g} \mathrm{VS}_{\text {added }}\right)$ & $598.7 \pm 13.3^{\mathrm{a}, \mathrm{B}}$ & $723.7 \pm 17.0^{\mathrm{b}, 2}$ & $289.8 \pm 8.6^{\mathrm{a}, \mathrm{A}}$ & $453.2 \pm 11.0^{\mathrm{b}, 1}$ \\
\hline $\begin{array}{c}\mathrm{R}_{\max }\left(\mathrm{Nml} \mathrm{CH}_{4} / \mathrm{g}\right. \\
\left.\mathrm{VS}_{\text {added }} / \text { day }\right)\end{array}$ & $34.3 \pm 2.9^{\mathrm{a}, \mathrm{B}}$ & $36.2 \pm 2.8^{a, 1}$ & $20.1 \pm 0.9^{\mathrm{a}, \mathrm{A}}$ & $35.0 \pm 2.4^{\mathrm{b}, 1}$ \\
\hline$\lambda$ (day) & $9.7 \pm 2.4^{\mathrm{a}, \mathrm{B}}$ & $9.0 \pm 0.2^{a, 2}$ & $0.2 \pm 0.1^{\mathrm{a}, \mathrm{A}}$ & $1.5 \pm 0.2^{b, 1}$ \\
\hline Correlation coefficient $\left(\mathrm{R}^{2}\right)$ & 0.999 & 0.999 & 0.989 & 0.991 \\
\hline $\mathrm{T}_{90}$ (days) & $30.7 \pm 0.7^{\mathrm{a}, \mathrm{B}}$ & $33.0 \pm 2.2^{\mathrm{a}, 2}$ & $17.4 \pm 0.3^{\mathrm{a}, \mathrm{A}}$ & $17.0 \pm 0.8^{\mathrm{a}, 1}$ \\
\hline$T_{\text {eff }}$ (days) & $20.9 \pm 1.8^{\mathrm{a}, \mathrm{B}}$ & $24.0 \pm 2.3^{\mathrm{a}, 2}$ & $17.2 \pm 0.2^{\mathrm{b}, \mathrm{A}}$ & $15.5 \pm 1.0^{\mathrm{a}, 1}$ \\
\hline
\end{tabular}

${ }^{*} M_{\text {max }}$ : Maximum $\mathrm{CH}_{4}$ potential production, $\mathrm{R}_{\max }$ : Maximum $\mathrm{CH}_{4}$ production rate, $\lambda$ : Lag phase period, $\mathrm{T}_{90}$ Time required to obtain $90 \%$ of $M_{\max }$, and $T_{\text {eff }}$ Effective digestion time $\left(\mathrm{T}_{90}-\lambda\right)$. ${ }^{* *}$ Values are expressed as mean \pm standard deviation. ${ }^{a, b}$ Means of the same substrate (SSW or SS) at different S/I ratios with different lowercase letters differ significantly $(p<0.05)$. ${ }^{\mathrm{A}, \mathrm{B}}$ Means at an S/I ratio of 1 with different uppercase letters differ significantly $(p<0.05) .{ }^{1,2}$ Means at an S/I ratio of 0.5 with different numbers differ significantly $(p<0.05)$.

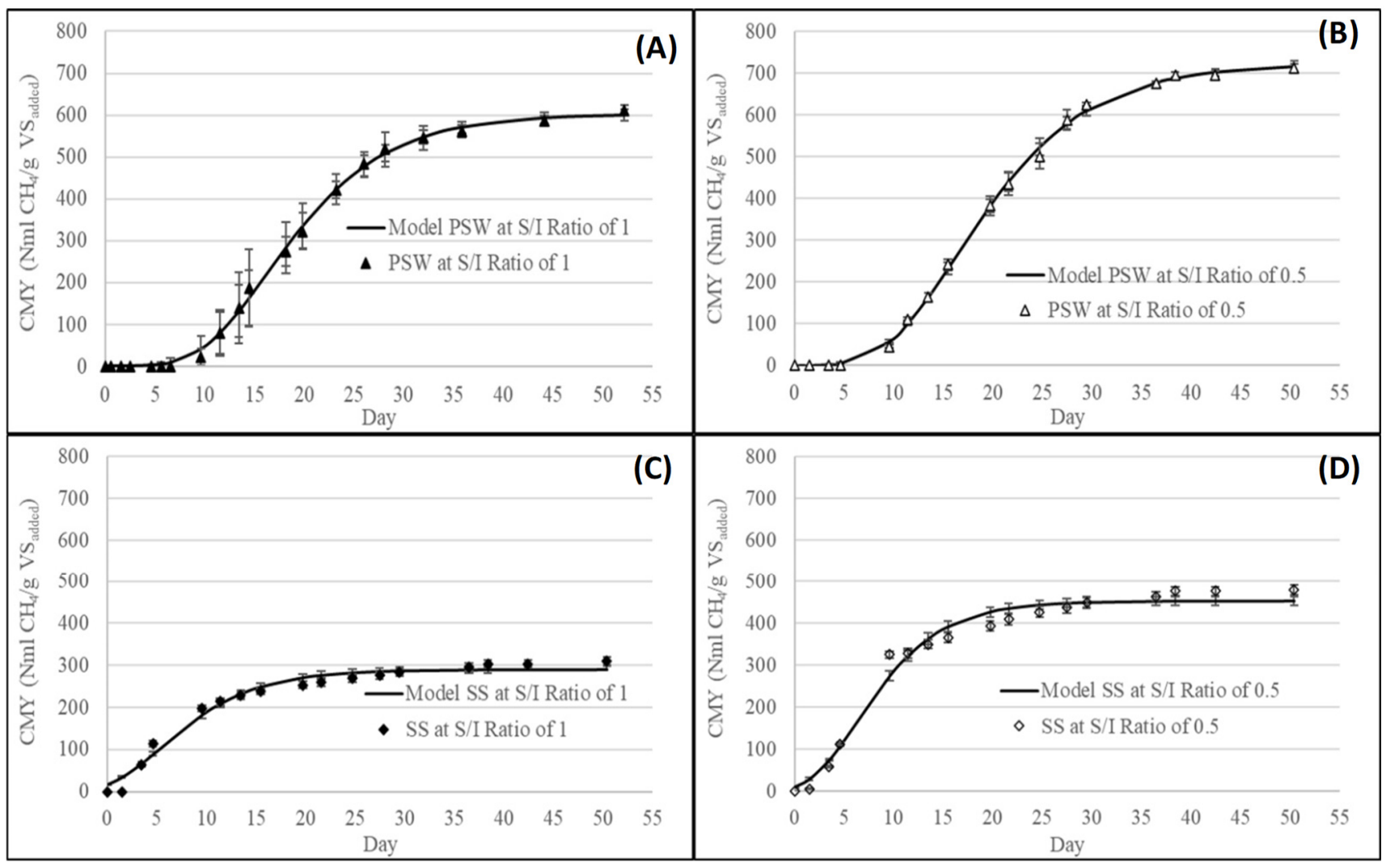

Figure 2. CMY estimated using the modified Gompertz formula (line) plotted against experimental CMY (bullet points) of SSW and SS. (A) SSW at an S/I ratio of 1, (B) SSW at an S/I ratio of 0.5, (C) SS at an S/I ratio of 1, and (D) SS at an S/I ratio of 0.5. PSW, pig slaughter waste equal to SSW.

However, the long $\lambda$ might affect the overall anaerobic reactor performance, especially the digestion times such as $\mathrm{T}_{90}$ and $T_{\text {eff }}$ (Table 5). $\mathrm{T}_{90}$ is defined as the time required to obtain $90 \%$ of $M_{\max }$ [30]. The $T_{90}$ calculated in this study was 30.7 and 33 days for SSW at an S/I ratio of 1 and 0.5 , respectively. Subtracting $T_{90}$ with $\lambda$ as $T_{\text {eff }}$ (effective digestion time) for SSW at an S/I ratio of 1 and 0.5 was 20.9 and 24 days, respectively. There was no significant difference for $\mathrm{T}_{90}$ and $T_{\text {eff }}$ at different $\mathrm{S} / \mathrm{I}$ ratios; however, these parameters were moderately higher in SSW than SS. $T_{\text {eff }}$ indicated that most $\mathrm{CH}_{4}$ production of SSW requires 20.9-24 days assuming that there is no $\lambda$ at the beginning of the digestion process. Thus, $\lambda$ occurrence made the digestion process longer than necessary. A long $\lambda, T_{90}$, and $T_{\text {eff }}$ might be caused by the high fat and low mineral content in the SSW, which takes more 
degradation time and inadequate nutrients. In practice, a long $\lambda, T_{90}$, and $T_{\text {eff }}$ for waste treatment increase the operational cost, which reduces the economic benefit of the systems; therefore, these parameters must be reduced during anaerobic digestion. The codigestion of SSW with other organic matters might be the solution to reduce those parameters during anaerobic digestion.

Interestingly, SS demonstrated a higher $\mathrm{R}_{\max }$ with a rapid degradation of vs. at a minimum $\lambda$ of 1.5 days and 0.2 days and at an S/I ratio of 0.5 and 1 , respectively. These indicated that SS might have a more available, soluble, organic compound for a bacterial community in the digester. Compared to SSW, SS produced less $M_{\max }$ at both S/I ratios. For instance, the $M_{\max }$ of SS was only $48.4 \%$ of SSW at an S/I ratio of 1 . However, SS had lower $\lambda, T_{90}$, and $T_{\text {eff }}$ which indicated that vs. in SS was easily degradable and soluble. However, SS had low $M_{\max }$ and SMY compared to SSW $(p<0.05)$ due to its low vs. content. SS showed a high FS content ( $32.4 \%$ DW) which indicated that it consisted of rich minerals that might benefit the anaerobic digestion process. On the other hand, a low SMY and $M_{\max }$ might indicate the unviable use of SS as a feedstock in anaerobic digestion. Therefore, the codigestion of SS with SSW might help to achieve a better digestion efficiency by reducing the $\lambda, T_{90}$, and $T_{\text {eff }}$, improving $\mathrm{CH}_{4}$ production, and thus becoming a viable option.

\subsection{Codigestion of SSW with SS}

The codigestion effects of SSW with the SS parameters are shown in Table 6. The codigestion increased $M_{\max }$ from 289.8 and $453.2 \mathrm{Nml} \mathrm{CH}_{4} / \mathrm{g} \mathrm{VS}_{\text {added }}$ to 405.1 and $672.4 \mathrm{Nml}$ $\mathrm{CH}_{4} / \mathrm{g} \mathrm{VS}_{\text {added }}$ at an S/I ratio of 1 and 0.5 , respectively. This was equal to a $22-84 \% M_{\max }$ increase compared to the sole digestion of SS. Moreover, codigestion had no significant effect on $T_{90}$ and $T_{\text {eff }}$ at both S/I ratios. This indicated that SSW codigestion with SS improved digestion efficiency in terms of higher $\mathrm{CH}_{4}$ generation with the help of a greater vs. addition from SSW. The mixing of SSW and SS increased the vs. content due to the high fat content in the SSW, and fat has a higher $\mathrm{CH}_{4}$ production potential than protein and carbohydrates.

Table 6. Anaerobic digestion parameters from codigestion of SSW with SS. The SSW content in the codigested mixture was $100 \%(\mathrm{P} 1), 0 \%(\mathrm{P} 2), 67 \%(\mathrm{P} 3), 50 \%(\mathrm{P} 4)$, and 33\% (P5) on a vs. basis.

\begin{tabular}{|c|c|c|c|c|c|c|c|c|c|c|}
\hline \multirow{2}{*}{ Parameters ${ }^{1}$} & \multicolumn{5}{|c|}{ S/I Ratio of $1^{2,3}$} & \multicolumn{5}{|c|}{ S/I Ratio of $0.5^{2,4}$} \\
\hline & P1A & P2A & P3A & P4A & P5A & P1B & P2B & P3B & P4B & P5B \\
\hline $\begin{array}{c}M_{\max }\left(\mathrm{Nml} \mathrm{CH}_{4} / \mathrm{g}\right. \\
\left.\mathrm{VS}_{\text {added }}\right)\end{array}$ & $\begin{array}{c}598.7 \pm \\
13.3^{\mathrm{e}}\end{array}$ & $\begin{array}{c}289.8 \pm \\
8.6^{\mathrm{a}}\end{array}$ & $\begin{array}{l}535.1 \pm \\
3.4^{\mathrm{d}}\end{array}$ & $\begin{array}{c}482.9 \pm \\
4.0^{c}\end{array}$ & $\begin{array}{l}405.1 \pm \\
5.3^{\mathrm{b}}\end{array}$ & $\begin{array}{c}723.7 \pm \\
17.0^{\mathrm{D}}\end{array}$ & $\begin{array}{c}453.2 \pm \\
11.0^{\mathrm{A}}\end{array}$ & $\begin{array}{l}672.4 \pm \\
11.3^{\mathrm{C}}\end{array}$ & $\begin{array}{l}634.8 \pm \\
9.3^{C}\end{array}$ & $\begin{array}{c}555.5 \pm \\
17.0^{\mathrm{B}}\end{array}$ \\
\hline $\begin{array}{c}\mathrm{R}_{\max }(\mathrm{Nml} \mathrm{CH} / \mathrm{g} \\
\left.\mathrm{VS}_{\text {added }} / \text { days }\right)\end{array}$ & $34.3 \underset{b}{ \pm} 2.9$ & $\begin{array}{c}20.1 \pm \\
0.9^{a}\end{array}$ & $44.7 \underset{\mathrm{b}}{ \pm} 4.0$ & $\begin{array}{l}42.9 \pm \\
1.5^{\mathrm{b}}\end{array}$ & $37.1 \underset{b}{ \pm} 9.5$ & $\begin{array}{c}36.2 \pm \\
2.8^{\mathrm{A}}\end{array}$ & $35.0 \pm 2.4$ & $\begin{array}{c}54.4 \pm \\
7.4^{\mathrm{B}}\end{array}$ & $\underset{\mathrm{B}}{48.3 \pm} 1.3$ & $\begin{array}{l}42.1 \pm \\
6.2^{\mathrm{AB}}\end{array}$ \\
\hline$\lambda$ (days) & $9.7 \pm 2.4^{c}$ & $\begin{array}{l}0.2 \pm \\
0.1^{\mathrm{a}}\end{array}$ & $5.2 \pm 2.3^{b}$ & $\begin{array}{l}2.4 \pm \\
0.8^{a}\end{array}$ & $1.2 \pm 0.7^{\mathrm{a}}$ & $\begin{array}{l}9.0 \pm \\
0.2^{\mathrm{E}}\end{array}$ & $1.5 \pm \underset{\mathrm{A}}{ \pm} 0.2$ & $\begin{array}{l}5.7 \pm \\
0.4^{\mathrm{D}}\end{array}$ & $4.0 \pm \underset{C}{ \pm} 0.2$ & $\begin{array}{l}3.0 \pm \\
0.2^{\mathrm{B}}\end{array}$ \\
\hline $\mathrm{R}^{2}$ & 0.999 & 0.989 & 0.999 & 0.998 & 0.997 & 0.999 & 0.991 & 0.998 & 0.997 & 0.996 \\
\hline $\mathrm{T}_{90}$ (days) & $30.7 \underset{\mathrm{b}}{ \pm} 0.7$ & $\begin{array}{c}17.4 \pm \\
0.3^{\mathrm{a}}\end{array}$ & $19.6 \pm \underset{\mathrm{a}}{ } 1.0$ & $\begin{array}{c}15.9 \pm \\
1.4^{\mathrm{a}}\end{array}$ & $14.9 \pm \underset{\mathrm{a}}{ \pm} 4.6$ & $\begin{array}{c}33.0 \pm \\
2.2^{\mathrm{B}}\end{array}$ & $\underset{\mathrm{A}}{17.0 \pm 0.8}$ & $\begin{array}{c}20.6 \pm \\
2.0^{\mathrm{A}}\end{array}$ & $19.7 \underset{\mathrm{A}}{ \pm} 0.4$ & $\begin{array}{c}18.9 \pm \\
1.7^{\mathrm{A}}\end{array}$ \\
\hline$T_{\text {eff }}$ (days) & $20.9 \pm \underset{b}{ \pm} 1.8$ & $\begin{array}{l}17.2 \pm \\
0.2^{\mathrm{ab}}\end{array}$ & $14.4 \pm \underset{\mathrm{a}}{ \pm} 1.3$ & $\begin{array}{c}13.5 \pm \\
0.6^{\mathrm{a}}\end{array}$ & $13.7 \pm \frac{\mathrm{a}}{\mathrm{a}} 3.9$ & $\begin{array}{c}24.0 \pm \\
2.3^{\mathrm{B}}\end{array}$ & $\underset{\mathrm{A}}{15.5} \mathbf{\pm} 1.0$ & $\begin{array}{c}14.9 \pm \\
2.4^{\mathrm{A}}\end{array}$ & $\underset{\mathrm{A}}{15.7 \pm 0.2}$ & $\begin{array}{c}15.9 \pm \\
1.8^{\mathrm{A}}\end{array}$ \\
\hline
\end{tabular}

${ }^{1} M_{\max }$ : maximum $\mathrm{CH}_{4}$ potential production, $\mathrm{R}_{\max }$ : maximum $\mathrm{CH}_{4}$ production rate, $\lambda$ : lag phase period, $\mathrm{R}^{2}$ : correlation coefficient, $\mathrm{T}_{90}$ : time required to obtain $90 \%$ of $M_{\max }$, and $T_{\text {eff }}$ : effective digestion time $\left(T_{90}-\lambda\right)$. ${ }^{2}$ Values are expressed as mean \pm standard deviation.

${ }^{3}$ Means in the same row at an S/I ratio of 1 (A) with different lowercase letters differ significantly $(p<0.05) .{ }^{4}$ Means in the same row at an

$\mathrm{S} / \mathrm{I}$ ratio of 0.5 (B) with different uppercase letters differ significantly $(p<0.05)$.

$M_{\max }$ of the codigested substrate at both S/I ratios was significantly lower than that for sole SSW digestion. The $M_{\max }$ obtained from the codigestion of SSW and SS was 535.1, 482.9 , and $405.1 \mathrm{Nml} \mathrm{CH}_{4} / \mathrm{g} \mathrm{VS}_{\text {added }}$ at mixing percentages of $67 \%, 50 \%$, and $33 \%$ of SSW at an S/I ratio of 1 , respectively. Meanwhile, at an S/I ratio of 0.5 , the $M_{\max }$ was $672.4,634.8$, and $555.5 \mathrm{Nml} \mathrm{CH}_{4} / \mathrm{g} \mathrm{VS}_{\text {added }}$ for the codigested mixture containing $67 \%, 50 \%$, and $33 \%$ 
of SSW, respectively. The codigested mixture reduced the $M_{\max }$ to $7-32 \%$ in comparison to the sole digestion of PWS.

Previous studies also revealed a more reduced $M_{\max }$ during the anaerobic codigestion of slaughter waste with other substrates, compared to sole digestion. Borowski and

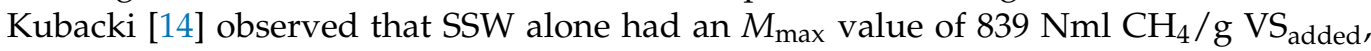
while, during the codigestion with sewage sludge at a mixing ratio of $30 \%$ and $50 \%$ weight per weight $(w / w)$, the $M_{\max }$ ranged from 472.8 to $608.6 \mathrm{Nml} \mathrm{CH}_{4} / \mathrm{g} \mathrm{VS}_{\text {added }}$. RodríguezAbalde et al. [18] obtained $M_{\max }$ of $430 \mathrm{Nml} \mathrm{CH}_{4} / \mathrm{g} \mathrm{VS}_{\text {added }}$ in the codigestion of $36 \% \mathrm{SSW}$ with $67 \%$ swine manure (SM). This was lower than that for SSW sole digestion $\left(M_{\max }\right.$ of $809 \mathrm{Nml} \mathrm{CH}_{4} / \mathrm{g} \mathrm{VS}_{\text {added }}$ ). The reduced $M_{\max }$ was attributed to the low methane potential in the codigested materials other than SSW.

However, the codigestion of SSW and SS had a significant effect on $\lambda, T_{90}$, and $T_{\text {eff }}$ (Table 6). The anaerobic digestion of sole SSW had the highest $\lambda, T_{90}$, and $T_{\text {eff }}$ at both $\mathrm{S} / \mathrm{I}$ ratios. All the codigested mixtures had a significantly lower $(p<0.05) \lambda, \mathrm{T}_{90}$, and $T_{\text {eff }}$ compared to sole SSW digestion (Table 6). Codigestion shortened the $\lambda$ from 9 and 9.7 days (sole digestion of SSW) to between 1.2 and 5.7 days (SSW and SS codigestion) at an S/I ratio of 1 and 0.5 , respectively. It also shortened the $T_{\text {eff }}$ from 20.9 and 24.0 days (SSW sole digestion) to between 13.5 and 15.7 days (SSW and SS codigestion) at an S/I ratio of 1 and 0.5 , respectively. $\mathrm{T}_{90}$ was also shortened from 30.7 and 33 days (SSW sole digestion) to 14.9-20.6 days (SSW and SS codigestion) at a S/I ratio of 1 and 0.5, respectively. The improved digestion properties such as $\lambda, T_{90}$, and $T_{\text {eff }}$ were attributed to the SS characteristics (dissolved OM and micronutrients) than SSW. SS had a high moisture content $(95.9 \% \mathrm{FW})$, indicating that the vs. and nutrients were mostly present in soluble form. Moreover, Table 7 shows that SS had higher cobalt (Co), iron (Fe), molybdenum $(\mathrm{Mo})$, nickel $(\mathrm{Ni})$, tungsten $(\mathrm{W})$, and zinc $(\mathrm{Zn})$ contents compared to SSW. The last stage of methanogenesis, $\mathrm{CH}_{3}-\mathrm{CoM}$ formation, was facilitated by the enzyme, methyltransferase. $\mathrm{Co}$ and $\mathrm{Ni}$ are known cofactors for the enzyme reaction $[40,42]$. This indicated that an adequate concentration of $\mathrm{Co}$ and $\mathrm{Ni}$ during anaerobic digestion was necessary. Shorter $\lambda$, $\mathrm{T}_{90}$, and $T_{\text {eff }}$ indicated that the codigestion of SSW and SS improved anaerobic digestion efficiency in terms of a shorter digestion time from an SSW perspective.

Table 7. Comparison of the mineral contents of SSW and SS.

\begin{tabular}{cccc}
\hline Mineral & SSW $^{\mathbf{1}}(\mathbf{m g} / \mathbf{k g})$ & SS $^{\mathbf{1}}(\mathbf{m g} / \mathbf{k g})$ & SSW/SS \\
\hline Cobalt (Co) & $0.3 \pm 0.0^{\mathrm{a}}$ & $10.4 \pm 0.1^{\mathrm{b}}$ & 0.03 \\
\hline Iron (Fe) & $229.3 \pm 46.4^{\mathrm{a}}$ & $10,872 \pm 136^{\mathrm{b}}$ & 0.02 \\
\hline Molybdenum (Mo) & $3.6 \pm 3.4^{\mathrm{a}}$ & $13.0 \pm 0.1^{\mathrm{b}}$ & 0.28 \\
\hline Nickel (Ni) & $2.9 \pm 0.4^{\mathrm{a}}$ & $25.0 \pm 0.1^{\mathrm{b}}$ & 0.12 \\
\hline Tungsten (W) & $0.0 \pm 0.0^{\mathrm{a}}$ & $22.1 \pm 0.0^{\mathrm{b}}$ & - \\
\hline Zinc (Zn) & $200.5 \pm 34.2^{\mathrm{a}}$ & $2239 \pm 20^{\mathrm{b}}$ & 0.09 \\
\hline
\end{tabular}

${ }^{1}$ Values are expressed as mean \pm standard deviation. ${ }^{a, b}$ Means in the same column with different lowercase letters differ significantly $(p<0.05)$.

Table 7 shows that the SSW only had a Co and Ni content of 0.3 and $2.9 \mathrm{mg} / \mathrm{kg}$, while SS contained 10.4 and $25 \mathrm{mg} / \mathrm{kg}$, respectively. The recommended Co and Ni content for anaerobic digestion was between 0.03 and $35 \mathrm{mg} / \mathrm{kg}$ [40]. This indicated that the low Co and $\mathrm{Ni}$ content in SSW was still adequate for anaerobic digestion. This was confirmed from the sole digestion of SSW, which showed a high $M_{\max }, D_{\text {deg, }}$ and SMY (Tables 4 and 5). However, a long $\lambda, T_{90}$, and $T_{\text {eff }}$ observed during the anaerobic digestion of SSW might indicate that both $\mathrm{Co}$ and $\mathrm{Ni}$ might not be readily available from the start of anaerobic digestion.

Mineral availability is an important factor in anaerobic digestion, and it exists in a soluble (free ions) form, complex form (organic or inorganic), and precipitate form [42-44]. 
A high vs. content of SSW might form a mineral complex with $\mathrm{Co}$ and $\mathrm{Ni}$, which makes it unavailable from the start of anaerobic digestion. After the vs. is digested through hydrolysis and acidification processes, the $\mathrm{Co}$ and $\mathrm{Ni}$ then become available to be utilized by the microorganisms. This might be one cause of the long $\lambda, T_{90}$, and $T_{\text {eff }}$ observed during the anaerobic digestion of SSW.

On the other hand, SS had low VSs with a higher moisture, $\mathrm{Co}$, and Ni content than SSW, which was attributed to the improved digestion (shorter $\lambda, T_{90}$, and $T_{\text {eff }}$ ) in the codigestion mixture compared to sole SSW digestion. Moreover, the effect of SSW and SS codigestion on other minerals and the anaerobic digestion parameters seems to be an interesting topic for further studies. Substrate codigestion can produce either a synergistic or an antagonistic effect. The antagonistic effect occurred when the experimental $M_{\max }$ was lower than the simulated $M_{\max }$, whereas the synergistic effect occurred when the experimental $M_{\max }$ was higher than the simulated $M_{\max }$ [31]. The experimental $M_{\max }$ of SSW codigestion, with an SS at an S/I ratio of 1 and 0.5 , showed an $\alpha$ value of more than 1 indicating that the synergistic effect occurred during the anaerobic codigestion of SSW and SS (Table 8). The combination of the high vs. and fat contents of SSW and highly soluble $\mathrm{OM}$, and $\mathrm{Co}$, and Ni contents of SS were the reason for the synergistic effect. Digestate characteristics are further recommended for a detailed analysis of their possible agricultural reuse, especially regarding heavy metals and microbiological parameters.

Table 8. Results of the synergistic or antagonistic effect produced by the codigestion of SSW with SS.

\begin{tabular}{cccc}
\hline Reactor $^{1}$ & Experimental $\boldsymbol{M}_{\text {max }}{ }^{2}$ & Simulated $\boldsymbol{M}_{\text {max }}{ }^{2}$ & $\mathbf{A}^{\mathbf{2 , 3}}$ \\
P1A & $598.7 \pm 13.3$ & $598.7 \pm 13.3$ & \\
P2A & $289.8 \pm 8.6$ & $289.8 \pm 8.6$ & $1.08 \pm 0.01$ \\
P3A & $535.1 \pm 3.4$ & $495.8 \pm 6.6$ & $1.09 \pm 0.01$ \\
P4A & $482.9 \pm 4.0$ & $444.3 \pm 3.7$ & $1.03 \pm 0.02$ \\
P5A & $405.1 \pm 5.3$ & $392.8 \pm 2.9$ & $1.07 \pm 0.02$ \\
P1B & $723.7 \pm 17.0$ & $723.7 \pm 17.0$ & $1.08 \pm 0.03$ \\
P2B & $453.2 \pm 11.0$ & $453.2 \pm 11.0$ & $1.02 \pm 0.02$ \\
P3B & $672.4 \pm 11.3$ & $633.5 \pm 14.6$ &
\end{tabular}

${ }^{1}$ The SSW content in the codigested mixture was 100\% (P1), 0\% (P2), 67\% (P3), 50\% (P4), and 33\% (P5) on a vs basis. A indicated that the experiment was conducted at an S/I ratio of 1, while B indicated that the experiment was conducted at an S/I ratio of $0.5 .{ }^{2}$ Values are expressed as mean \pm standard deviation; unit in $\mathrm{Nml} \mathrm{CH}_{4} / \mathrm{g}$ VS $_{\text {added. }}{ }^{3} \alpha=$ Experimental $M_{\max } /$ Simulated $M_{\max }$ (Equation (6)).

\section{Conclusions}

In this study, we conclude that the SSW and SS have significant biomethane production potential. However, the anaerobic codigestion of SSW and SS improves the $\lambda$ and $T_{\text {eff, }}$ as well as causing a considerable amount of methane production. SSW contributes more organic matter, while SS provides more minerals for the improved digestion. The substrate to inoculums ratio affects methane production, significantly. Experimental and simulated methane yields are correlated. Still, the exact mechanisms of the shorter $\lambda$ and $T_{\text {eff }}$ of SSW codigestion with SS are not clear. Hence, the codigestion effect on mineral availability and anaerobic digestion parameters seems to be an interesting topic for future research.

Author Contributions: Conceptualization, A.R., S.I.A.S. and H.L.C.; methodology, A.R. and S.I.A.S.; software, A.R.; validation, A.R., S.I.A.S. and A.F.; formal analysis, A.R. and S.I.A.S.; investigation, A.R.; resources, A.R., A.F. and S.I.A.S.; data curation, A.R., A.F. and H.L.C.; writing-original draft preparation, A.R., H.L.C. and A.S.; writing-review and editing, A.R., S.I.A.S., A.F., H.L.C., D.H.A., Y.W.C. and A.S.; visualization, A.R. and A.F.; supervision, H.L.C., D.H.A. and Y.W.C.; project administration, H.L.C., D.H.A. and Y.W.C.; and funding acquisition, H.L.C., D.H.A. and Y.W.C. All authors have read and agreed to the published version of the manuscript. 
Funding: This research was funded by Korea Institute of Planning and Evaluation for Technology in Food, Agriculture, Forestry and Fisheries (iPET), project number 116049-3, Ministry of Agriculture, Food, and Rural Affairs, Republic of Korea.

Institutional Review Board Statement: Not applicable.

Informed Consent Statement: Not applicable.

Data Availability Statement: The data presented in this study are available on request from the corresponding author.

Acknowledgments: The authors want to express their gratitude to Seoul National University (SNU) Global Scholarship, SNU Lecture \& Research Scholarship, SNU Merit-based Scholarship, and Farmsco Co., Ltd. for the financial support the author received during his doctoral program.

Conflicts of Interest: The authors declare no conflict of interest.

\section{References}

1. Lee, J.; Koo, T.; Han, G.; Shin, S.G.; Hwang, S. Anaerobic digestion of cattle offal: Protein and lipid-rich substrate degradation and population dynamics of acidogens and methanogens. Bioprocess Biosyst. Eng. 2015, 38, 2349-2360. [CrossRef] [PubMed]

2. APQA. Animal and Plant Quarantine Agency, Republic of Korea. 2017. Available online: http://www.qia.go.kr/livestock/clean/ listTcsjWebAction.do?clear=1 (accessed on 18 August 2017).

3. Alvarez, R.; Liden, G. Semi-continuous co-digestion of solid slaughter waste, manure, and fruit and vegetable waste. Renew. Energy 2008, 33, 726-734. [CrossRef]

4. Cuetos, M.J.; Gómez, X.; Otero, M.; Morán, A. Anaerobic digestion of solid slaughter waste (SHW) at laboratory scale: Influence of co-digestion with the organic fraction of municipal solid waste (OFMSW). Biochem. Eng. J. 2008, 40, 99-106. [CrossRef]

5. Yoon, Y.-M.; Kim, S.-H.; Shin, K.-S.; Kim, C.-H. Effects of substrate to inoculum ratio on the biochemical methane potential of swinegery slaughter wastes. Asian-Australas. J. Anim. Sci. 2014, 27, 600. [CrossRef] [PubMed]

6. Nazifa, T.H.; Saady, N.M.C.; Bazan, C.; Zendehboudi, S.; Aftab, A.; Albayati, T.M. Anaerobic digestion of blood from slaughtered livestock: A review. Energies 2021, 14, 5666. [CrossRef]

7. Suresh, A.; Choi, H. In situ rapid estimation of nutrients and organic matter in swine slurry by a hydrometer. Appl. Eng. Agric. 2012, 28, 935-942. [CrossRef]

8. Renggaman, A.; Choi, H.L.; Suresh, A. Underground anaerobic digester to solve the energy balance problem in temperate regions: A pilot study. Appl. Eng. Agric. 2015, 31, 643-651.

9. Suresh, A.; Choi, H.; Oh, D.; Moon, O. Prediction of the nutrients value and biochemical characteristics of swine slurry by measurement of EC-Electrical conductivity. Bioresour. Technol. 2009, 100, 4683-4689. [CrossRef]

10. Kim, Y.-S.; Yoon, Y.-M.; Kim, C.-H.; Giersdorf, J. Status of biogas technologies and policies in South Korea. Renew. Sustain. Energy Rev. 2012, 16, 3430-3438. [CrossRef]

11. Møller, H.B.; Nielsen, A.M.; Nakakubo, R.; Olsen, H.J. Process performance of biogas digesters incorporating pre-separated manure. Livest. Sci. 2007, 112, 217-223. [CrossRef]

12. Castellucci, S.; Cocchi, S.; Allegrini, E.; Vecchione, L. Anaerobic digestion and co-digestion of slaughterhouse wastes. J. Agric. Eng. 2013, 44, s2. [CrossRef]

13. Mainardis, M.; Cabbai, V.; Zannier, G.; Visintini, D.; Goi, D. Characterization and BMP tests of liquid substrates for high-rate anaerobic digestion. Chem. Biochem. Eng. Q. 2017, 31, 509-518. [CrossRef]

14. Borowski, S.; Kubacki, P. Co-digestion of swine slaughter waste with sewage sludge. Waste Manag. 2015, 40, 119-126. [CrossRef]

15. Mata-Alvarez, J.; Dosta, J.; Macé, S.; Astals, S. Codigestion of solid wastes: A review of its uses and perspectives including modeling. Crit. Rev. Biotechnol. 2011, 31, 99-111. [CrossRef]

16. Pagés-Díaz, J.; Westman, J.; Taherzadeh, M.J.; Pereda-Reyes, I.; Horváth, I.S. Semi-continuous co-digestion of solid cattle slaughter wastes with other waste streams: Interactions within the mixtures and methanogenic community structure. Chem. Eng. J. 2015, 273, 28-36. [CrossRef]

17. Mata-Alvarez, J.; Dosta, J.; Romero-Güiza, M.; Fonoll, X.; Peces, M.; Astals, S. A critical review on anaerobic co-digestion achievements between 2010 and 2013. Renew. Sustain. Energy Rev. 2014, 36, 412-427. [CrossRef]

18. Rodríguez-Abalde, Á.; Flotats, X.; Fernández, B. Optimization of the anaerobic co-digestion of pasteurized slaughter waste, swine slurry and glycerine. Waste Manag. 2017, 61, 521-528. [CrossRef]

19. Fernández-Cegrí, V.; De la Rubia, M.Á.; Raposo, F.; Borja, R. Effect of hydrothermal pretreatment of sunflower oil cake on biomethane potential focusing on fibre composition. Bioresour. Technol. 2012, 123, 424-429. [CrossRef]

20. APHA. Standard Methods for the Examination of Water $\mathcal{E}$ Wastewater, 21st ed.; American Public Health Association: Washington, DC, USA, 2005.

21. Choi, H.L.; Sudiarto, S.I.A.; Renggaman, A. Prediction of livestock manure and mixture higher heating value based on fundamental analysis. Fuel 2014, 116, 772-780. [CrossRef] 
22. Himanshu, H.; Voelklein, M.A.; Murphy, J.D.; Grant, J.; O'Kiely, P. Factors controlling headspace pressure in a manual manometric BMP method can be used to produce a methane output comparable to AMPTS. Bioresour. Technol. 2017, 238, 633-642. [CrossRef]

23. Valero, D.; Montes, J.A.; Rico, J.L.; Rico, C. Influence of headspace pressure on methane production in Biochemical Methane Potential (BMP) tests. Waste Manag. 2016, 48, 193-198. [CrossRef]

24. Symons, G.; Buswell, A. The methane fermentation of carbohydrates. J. Am. Chem. Soc. 1933, 55, 2028-2036. [CrossRef]

25. Boyle, W. Energy recovery from sanitary landfills-A review. In Microbial Energy Conversion; Elsevier: Amsterdam, The Netherlands, 1977; pp. 119-138. [CrossRef]

26. Moukazis, I.; Pellera, F.-M.; Gidarakos, E. Slaughter by-products treatment using anaerobic digestion. Waste Manag. 2018, 71, 652-662. [CrossRef]

27. Pellera, F.-M.; Gidarakos, E. Effect of substrate to inoculum ratio and inoculum type on the biochemical methane potential of solid agroindustrial waste. J. Environ. Chem. Eng. 2016, 4, 3217-3229. [CrossRef]

28. Rao, M.; Singh, S.; Singh, A.; Sodha, M. Bioenergy conversion studies of the organic fraction of MSW: Assessment of ultimate bioenergy production potential of municipal garbage. Appl. Energy 2000, 66, 75-87. [CrossRef]

29. Zhang, W.; Wei, Q.; Wu, S.; Qi, D.; Li, W.; Zuo, Z.; Dong, R. Batch anaerobic co-digestion of swine manure with dewatered sewage sludge under mesophilic conditions. Appl. Energy 2014, 128, 175-183. [CrossRef]

30. Kafle, G.K.; Kim, S.H. Anaerobic treatment of apple waste with swine manure for biogas production: Batch and continuous operation. Appl. Energy 2013, 103, 61-72. [CrossRef]

31. Nielfa, A.; Cano, R.; Fdz-Polanco, M. Theoretical methane production generated by the co-digestion of organic fraction municipal solid waste and biological sludge. Biotechnol. Rep. 2015, 5, 14-21. [CrossRef] [PubMed]

32. Hejnfelt, A.; Angelidaki, I. Anaerobic digestion of slaughter by-products. Biomass Bioenergy 2009, 33, 1046-1054. [CrossRef]

33. Ware, A.; Power, N. What is the effect of mandatory pasteurisation on the biogas transformation of solid slaughter wastes? Waste Manag. 2016, 48, 503-512. [CrossRef]

34. Nhuchhen, D.R.; Salam, P.A. Estimation of higher heating value of biomass from proximate analysis: A new approach. Fuel 2012, 99, 55-63. [CrossRef]

35. Yin, C.Y. Prediction of higher heating values of biomass from proximate and ultimate analyses. Fuel 2011, 90, 1128-1132 [CrossRef]

36. Lijó, L.; González-García, S.; Bacenetti, J.; Moreira, M.T. The environmental effect of substituting energy crops for food waste as feedstock for biogas production. Energy 2017, 137, 1130-1143. [CrossRef]

37. Chae, K.; Jang, A.; Yim, S.; Kim, I.S. The effects of digestion temperature and temperature shock on the biogas yields from the mesophilic anaerobic digestion of swine manure. Bioresour. Technol. 2008, 99, 1-6. [CrossRef]

38. Neves, L.; Oliveira, R.; Alves, M. Influence of inoculum activity on the bio-methanization of a kitchen waste under different waste/inoculum ratios. Process Biochem. 2004, 39, 2019-2024. [CrossRef]

39. Xie, S.; Lawlor, P.G.; Frost, J.P.; Hu, Z.; Zhan, X. Effect of swine manure to grass silage ratio on methane production in batch anaerobic co-digestion of concentrated swine manure and grass silage. Bioresour. Technol. 2011, 102, 5728-5733. [CrossRef]

40. Guo, J.; Peng, Y.; Ni, B.-J.; Han, X.; Fan, L.; Yuan, Z. Dissecting microbial community structure and methane-producing pathways of a full-scale anaerobic reactor digesting activated sludge from wastewater treatment by metagenomic sequencing. Microb. Cell Factories 2015, 14, 33. [CrossRef]

41. Silvestre, G.; Rodríguez-Abalde, A.; Fernández, B.; Flotats, X.; Bonmatí, A. Biomass adaptation over anaerobic co-digestion of sewage sludge and trapped grease waste. Bioresour. Technol. 2011, 102, 6830-6836. [CrossRef]

42. Choong, Y.Y.; Norli, I.; Abdullah, A.Z.; Yhaya, M.F. Impacts of trace element supplementation on the performance of anaerobic digestion process: A critical review. Bioresour. Technol. 2016, 209, 369-379. [CrossRef]

43. Romero-Güiza, M.; Vila, J.; Mata-Alvarez, J.; Chimenos, J.; Astals, S. The role of additives on anaerobic digestion: A review. Renew. Sustain. Energy Rev. 2016, 58, 1486-1499. [CrossRef]

44. Ortner, M.; Rameder, M.; Rachbauer, L.; Bochmann, G.; Fuchs, W. Bioavailability of essential trace elements and their impact on anaerobic digestion of slaughter waste. Biochem. Eng. J. 2015, 99, 107-113. [CrossRef] 